\title{
Berlin Devlet Kütüphanesinde Bulunan Bazı Minyatürlerdeki Ejderha Figürü Metaforu Üzerine Bir İnceleme
}

\author{
An Analysis on The Metaphor of Dragon Figure in Some Miniatures in The \\ Berlin State Library
}

\author{
Sevda Emlak \\ Dr. Öğr. Üyesi, İzmir Demokrasi Üniversitesi Güzel Sanatlar Fakültesi Geleneksel Türk Sanatları Bölümü \\ email: sevda.emlak@idu.edu.tr (DORCID ID: https://orcid.org/0000-0001-5311-6726
}

Atıf (APA 6)/To cite this article

Emlak, S. (2019). Berlin devlet kütüphanesinde bulunan bazı minyatürlerdeki ejderha figürü metaforu üzerine bir inceleme. Atatürk Üniversitesi Güzel Sanatlar Enstitüsü Dergisi, 43, 140-149. doi: https://doi.org/10.32547/ataunigsed.588450

Makale Gönderim Tarihi/Received: 08/07/2019

Makale Kabul Tarihi/Accepted: 29/09/2019

Makale Yayın Tarihi/Published: 26/10/2019

Review Article/Derleme Makalesi

\section{$\ddot{O} z$}

Minyatür sanatında konu alınan hayvan tasvirleri, taşıdıkları simgeleri yazma eserin ihtiva ettiği bilgiyi bütünlemek için tercih edilmektedir. Minyatürlerde bulunan Ejderha figürlerinin betimleme sahneleri ejderhanın sembolik olarak farklı anlamları ile tasvir edilebilmektedir. Bu metaforlar gerçek ve sembol anlamları dahilinde geliștirilmektedir. Ejderhalar mimari, seramik, dokuma ve yazma eser tasvirlerinde sıkça rastladığımız bir hayvan figürüdür. Farklı yüzyıllarda ceșitli konular üzerine yazılmış eserlerin betimlemelerinde gördüğümüz bu figürün metaforu minyatürde ifade edilmek istenen unsurun sembolü olarak kullanılabileceği gibi metnin içeriğine bağımlı olarak betimlendiği de bilinmektedir

Calıșada Berlin Devlet Kütüphanesinde bulunan XV ve XX yüzyıllar arası ejderha figürünün betimlendiği bazı minyatür sahneleri seçilmiştir. Eserlerde bulunan ejderha tasvirlerinin sembolize ettiği unsurlar ele alınmıștır. Minyatürlerde Behram Gur'un bir Ejderha ile dövüş sahnesi, Rüstem ve Atı'nın bir Ejderhayı öldürmesi, Güștasp'ın bir ejderhayı öldürmesi minyatürleri kahramanların ejderha ile savaşını betimlerken, aşk mesnevilerinden olan Vâmık u Azra eserinden garip mahlûkatların mağarada uyuyan Vâmık'ı kuşatması sahnesi bulunmaktadır. Resim 3, 5 ve 7‘de ise Hz. Musa'nın asasının ejderhaya/yılana dönüşümü konularına yer verilmiştir.

Araştırmanın sonucunda farklı üslup ve tekniklerle karşımıza çıkan minyatürlerin ejderha sahnelerinde konu benzerlikleri görülürken üslup farklılıkları göze çarpmaktadır. Minyatür betimlemelerinde ejderha figürleri metaforik anlamları itibari ile incelenmiş ele alınan tasvirlerde kahramanlık, bereket, peygamberlere verilen ilahi güç ve kötülük/sinsilik sembolleri olarak ele alındığı görülmüştür. Minyatürlerdeki ejder motifi sembolize ettiği güc ve metaforik anlamlan itibari ile kullanılmış olsa da Eser 5'teki minyatürde resmedilen yılan figürü sinsilik ve kötülük mahiyetinde farklı bir anlam içermektedir. Birkaç farklı konuda resmedilen ejderha figürlerinin ağzından alev çıkaran sahnelerde ise şimşek ve bereket ile özdeșleștiği, savas sahnelerinde ise güç ve erdem unsurlarının metaforlarına başvurulduğu görülmüştür.

Anahtar kelimeler: Yazma Eser, Minyatür, Ejderha, Berlin Devlet Kütüphanesi

\begin{abstract}
Animal depictions in miniature art are preferred to complement the information in the manuscript. Descriptive scenes of dragon figures in miniatures can be depicted with symbolic commutative meanings of the dragon. These metaphors are developed within the literal and symbolic meanings. Dragon is an animal figure that we often come across in architectural, ceramic, weaving and manuscript descriptions. It is known that the metaphor of this figure, which we see in the descriptions of the works written on various subjects in different centuries, can be used as a symbol of the element to be expressed in miniature or it is depicted depending on the content of the text.
\end{abstract}

Some miniature scenes depicting dragon figures between fifteenth and twentieth centuries in the Berlin State Library were selected. The elements symbolized by the dragon depictions in the works are discussed. In the miniatures, Behram Gur's fighting scene with a Dragon, Rustem and his Horse killing a Dragon, and Gestasp killing a dragon depict the heroes' war with the dragon while there is a scene of Vâmık sleeping in the cave and surrounded by odd creatures from Vâmık u Azra which is one of the love mesnevis. Figures 3, 5 and 7 show the conversion of Moses' wand to a dragon / snake.

As a result of the research, in the miniatures that have different styles and techniques, similarities are seen in the dragon scenes in terms of content while the differences in style are noteworthy. In miniature descriptions, dragon figures are examined with respect to their metaphorical meanings, and it is seen that heroism, fertility, divine power given to prophets and evil / insidious symbols are considered. Although the dragon motif in the miniatures is used in terms of the power and symbol meanings it symbolizes, the snake figure depicted in the miniature in Figure 5 contains a changeable meaning of insidiousness and evil. It is seen that dragon figures depicted in several different subjects are identified with lightning and blessings in the scenes that emit flame from the mouth, and metaphors of power and virtue are used in war scenes.

Keywords: Manuscript, Miniature, Dragon, State Library of Berlin

\section{Giriș}

Kitap sanatlarında özellikle minyatür ve ciltlerde işlenen hayvan figürlerinin metaforik açılımları, sanatçının metne dayalı ya da bağımsız bir imge yaratma çabasından kaynaklanmaktadır. Minyatürlerdeki hayvan figürlerinin sembolize edilerek somut örneklerle ifade biçiminde metaforlara başvurulduğu görülmektedir. Bu 
şekilde bir hayvan figürünün resimdeki tasvir biçiminden neyi işaret ettiğini ya da ifade ettiği anlaşılabilmektedir.

Metafor; "Bir ifadeyi, anlamlı bağlantısı olan bir başka ifade ile mecazi olarak anlatmak" şekliyle tanımlanmaktadır (Keklik, 1990, s. 1). "Metafor minyatür şiirdir." diyen Monroe Beardsley metaforların yaratıcılığını ifade ederken zihnimizde mevcut ve aşikâr olan benzerliklerin, ilişkilerin ve görüşlerin ötesine, kendi yarattığımız yeni benzerliklere, ilişkilere ve görüşlere yönlendiğini belirtmektedir. Lakoff ve Johnson (1980)'a göre metafor keşiftir; çünkü bu kelimenin tek başına bir anlam taşıyamayacağı boyutu keşfedilir ve hem kelimenin hem de düşüncenin anlam ufku genişler (Lakoff \& Johnson, 1980, s. 9-10).

Bir ünlü bilgin olan G. Viko'nun bir ifadesinde (1668-1744), insanlar sadece semboller ile konuşup yazmazlar, ayrıca semboller ve kelimeler ile düşünürler diye belirtmiştir. Viko'nun yorumundaki düşünceye göre mitte metafor kullanmak yararlı bir yöntemdir. Bundan dolayı her bir metafor dikkatli incelendiğinde, küçük bir mit olduğu anlaşılmaktadır. Farkların ise sadece kullanılan metaforlarda olduğunu belirtmiştir (aktaran Şahan, 2014, s. 20).

Hikâyelerde bazen, metaforlarda ise genellikle hayvanlar birer teşbih unsuru olarak kullanılmıştır (Nur, 2013, s. 18-30). Hayvan metaforu Dünya edebiyatında yaygın bir şekilde işlenmiştir. Bilhassa doğu edebiyatında daha eski ve köklü bir gelenektir. Türk edebiyatında ise hayvan metaforları ayrı bir önemle ele alınmıştır (Eke, 2016, s. 12-24). Türkmen masallarında işlenen dev, at, simurg ve ejderhalar ise belirgin vasıfları ile en yaygın mitik hayvanlardır (Gökçimen, 2010, s. 165-178). Eski Türk inanışında hayvana verilen önemin sebeplerinden bazıları hayvanların kutsal ya da uğurlu sayılmasıdır (Eke, 2016, s.12-24). İyi ya da kötü özellikleri ve olağanüstü güçleri olan bu hayvanlar, Türk mitolojisinden ve komşu mitolojilerinden izler taşımaktadır (Gökçimen, 2010, s. 165-178). Bu hayvan metoforları içerisinden ejderha figürü sembolleri üzerinde durulacaktır.

Ejderin sözlük anlamı; büyük yılan, masallarda ve mitolojide ki yılan figürünü andıran korkunç bir hayvan olarak ifade edilir. Ejder motifinin sembolizmi; su, gök ve yer öğelerine bağlı olarak büyük bir uygulama sahası bulmaktadır (Tez, 2008, s. 44). Temelde gök ve yer olmak üzere temsili olarak ikiye ayrılmaktadır. Kozmolojik unsurlara nazaran su ejderi, ağaç ejderi gibi ejderler de bulunmaktadır (Çoruhlu, 2014, s. 222). Yaratıklar içerisinde en çok bilinen ve önemli bir hayvan figürü olan ejderhanın değişik türleri mevcuttur. Bazı tasvirlerde kanatları vardır, kiminin ağzından alev çıkar, tek başlı, üç başlı, yedi başlı betimlemeleri bulunmaktadır (And, 2004, s. 392).

Ejderhaya Çinliler 'lung', Moğollar 'moghur', Araplar ‘tannin', İranlılar 'ejderha' adını vermişlerdir. Türklerde 'evren' olarak adlandırılmaktadır (Tez, 2008, s. 44). Ejder (tasvirlerde yılan) figürü çok eski dönemlerden itibaren çeşitli yapıtlarda kullanılmış (Toscanne, 1911, s. 204) Çin kaynaklı bir motiftir (Öğel, 2002, s. 566).

Ejderha Orta Asya inançlarına göre kahramanlık, iyilik, kötülük, yiğitlik, mertlik (Roux, 2005, s. 84) ve sağlık gibi metaforik açılımları temsil eder. Ejder sembolü dünyanın dönmesini ve gece, gündüz oluşumunun meydana gelmesini temin etmektedir (Özkeçeci ve Özkeçeci, 2007, s. 108). Bazen kanatlı olarak betimlenirken, eski Türk inanışlarına göre de gökyüzüne çıkarak bulutların arasında uçan, rüzgâr ve yıldırımın rolünü üstlenerek yağmurun yağmasını sağladığı belirtilmiştir. Bu şekilde Türk mitolojisinde bolluk ve yeniden doğuşun sembolü olarak bilinmektedirler (Çoruhlu, 1993, s. 48). Kök Türklerin Temir ırmağındaki gök-su tanrısı olarak da temsili bir sembolü ifade eder (Esin, 2003, s. 35). Çin ressamlarının çok düşkün bulundukları fantastik ejderhalar (Yurdaydın, 1954, s. 31-54) Türk destanlarında, menkıbelerde, masal ve efsanelerde çok sık rastlanan bir hayvan motifidir. Ejderha, toplumların yaşadıkları coğrafya ve inanç yapısına göre farklı şekillerde düşünülmektedir. Çin mitlerinde ejderha, suda yaşayan pullu bir canlı (Ocak, 1983, s. 177), Fars kültüründe ise kanatl1, dört ayakl1, ağzından alevler püskürten, (Onay, 1992, s. 178) gövdesi yılana benzeyen aslanpençeli, korkunç başlı, büyük kanatlı, iri cüsseli, yenilmez bir hayvan olarak tasvir edilir (Özkeçeci ve Özkeçeci, 2007, s. 108).

Ejderha aynı zamanda ağzından çıkardığı alevlerden dolayı şimşek ve bereket ile özdeşleşmektedir. Bu sebepten dolayı hükümranlık ve hayatın dengesini sağlayıcı bir sembol olarak da ifade edilmektedir (Ersoy, 2007, s. 243).

İran mitolojisinin ana konularından olan kahramanlar ile ejderhaların savaşları minyatürlerde farklı tasvirlerle yer almıştır. Feridûn üç başlı ejderhayla savaşarak Cemşid’in kız kardeşlerini kurtarması, Rüstem, Dîv-i Sepîd ile mücadele ederek Kavûs'u kurtarması, Güştasp ejderhalarla savaşarak suları onların egemenliğinden kurtarması (Yıldırım, 2012, s. 196) gibi sahnelerde ejderha figürü ile karşılaşırız. Arapça ve Farsça yazılmış Behram-ı Gur'un hayatını av ve aşk maceralarını anlatan şiirlerden oluşan Firdevsî’nin Şehnâmesi, Genceli Nizâmî’nin Heft Peyker, Hâtifî’nin Heft Manzar, Ali Şir Nevâînin Seb‘a-i Seyyâre ve Emîr Hüsrev-i Dihlevî'nin Heşt Bihişt adlı mesnevileri ile birlikte birçok menkıbelere konu olan (Konukçu, 1992, s. 453) Behram Gur'un ejderha ile savaşması, ejderhayı öldürmesi gibi minyatür sahnelerinde bu hayvan figürü sıkça 
görmekteyiz. Bu efsanevi mevcudatlar İç Asya mitolojisinde çağlar boyu süreklilik göstermiştir. Ejderha figürüne bezemelerde yer verilişin sebepleri arasında taşıdıkları hükümdarlara layık güç, egemenlik ve erdem gibi niteliklerin de göz önünde bulundurulduğunu düşündürmektedir (Mahir, 1993, s. 273-277).

Hz Ali'nin Hâveran Şahı Kubat ile cenglerini anlatan Hâvernâme’lerin birçok minyatürlü nüshalarında ejderha figürüne rastlamaktayız. Diğer yandan Şehname’ye benzeyen Darabname'lerde de ejderha tasvirleri bulunmaktadır (And, 2007, s. 326).

İskendernâme, Battalnâme, Saltuknâme gibi eserlerde Hz. Âdem ve Hz. Havva'nın cennetten kovulduğunu tasvir eden minyatürlerde şeytan kimi zaman yılan kimi zaman da ejderha olarak betimlenmiştir. Hz. Musa'nın Firavun' un önünde asasını dönüştürdüğünde bazı minyatürlerde yine ejderha ya da yılan betimlemeleri görülmektedir. Hz. Muhammed'in (S.A.V.) ejderha ile konuşması, İki dağ arasında bir ejderhayı sıkıştırması, Kâbe'nin temelinde çıkan ejderhanın Ukap kuşu tarafından gökyüzüne kaldırılması gibi mucizelerin minyatür sahnelerinde yine ejderha betimlemeleri yer almaktadır (And, 2007, s. 323).

Ansiklopedik bilgiler içeren Acaibü'l-Mahlûkat gibi eserlerde gökcisimlerinde de ejderhayı buluyoruz. Burada ejderha takımyıldızlarından biridir. Bunun adı ejderha anlamı veren Tinnîndir. Küçükayı takımyıldızını çepeçevre sarar S harfi gibi kıvrılarak bir yıldız dikdörtgeni oluşur (And, 2007, s. 323).

Mesnevilerdeki ejderha metaforu ise nefsi ifade etmek için kullanılmıştır. "Putların kaynağı ve anası nefsinizdir. Diğer putlar yılan ise nefs ejderhadır" diye buyuran Hz. Mevlâna nefsin sinsi olduğunu ve dilimizde yılanın sinsice kötülük yapanlara söylendiği vurgulanmıştır (Nur, 2013, s. 29-47). Metaforların tasvirlerdeki kullanımı betimlemenin gereği ya da farklı anlamları ile birlikte sanatçının tasavvuru ile ortaya çıkmaktadır.

Çalışmada ejderha figürlerinin metaforik anlamlarına yönelik unsurlar ele alınmıştır. Bu figürün minyatür tasvirlerinde işlenen konulara göre betimlemeleri verilerek hangi sembolleri ifade ettiği vurgulanmıştır.

Berlin Devlet Kütüphanesi'nde bulunan ejderha figürlü minyatürlerde kullanılan metaforlar üzerinde durmak ve incelenen yedi eserin minyatür sahneleri bilgilerini çıkarmak araştırmanın amacıdır. Minyatür sahneleri tasvir edilerek, ejderha figürünün temsilen anlamlar üzerinde durulmuştur.

\section{Yöntem}

$\mathrm{Bu}$ araştırma betimsel bir araştırma yöntemine dayalıdır. Araştırmanın verileri Berlin Devlet Kütüphanesi Yazma eser dijital veri tabanından elde edilmiştir. Literatür taraması yapılmış, verilerin analizi ve değerlendirilmesinde ele alınan minyatürlerdeki ejderha figürünün metaforlarına yer verilmiştir.

\section{Berlin devlet kütüphanesindeki ejderha figürlü minyatür sahneleri}

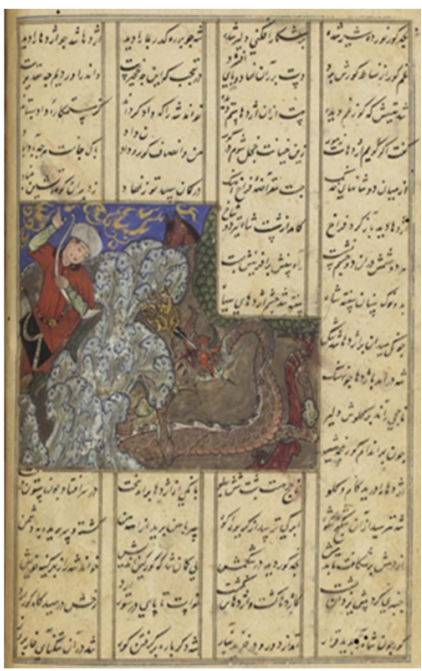

Resim 1. Behram-1 Gur ile bir ejderhanın dövüşs sahnesi (Berlin Devlet Kütüphanesi, VOHD 16,1,6)

Hamse, Berlin Devlet Kütüphanesi, VOHD 16,1, 6 İran Farsça 728 envanter kayıtlı, ppn: 729902676 numara ile sınıflandırılmıştır. Yazma eserin Müellifi Nizameddin İlyas Bin Yusuf, Nizami Gencevi'dir. Müstensihi bilinmeyen nüshanın dili Farsçadır. Eser 278 varaktan oluşmaktadır. İçerisinde 48 minyatürü olan eserin 4'ü çalınmıştır halen mevcut 44 minyatürü bulunmaktadır. Genel özelliklerinden 15. yüzyılın ortalarına tarihlendirilen eserin sayfa boyutu $22 \times 15 \mathrm{~cm}$ 'dir. Minyatür ise $6,7 \times 8,3 \mathrm{~cm}$ ölçülerindedir. Eserin beşinci bölümü eksiktir. Konusu şiir olan eserin minyatürlerinin birçoğu kötü durumdadır. Minyatürlerin üst üste gelen sayfaları zarar görmüştür. Ancak eserin bazı sayfaları yıpranmış olmasına rağmen orijinal tarzını hala korumaktadır. 
Minyatürde Sasani hükümdarı (420-438) Behram-ı Gur ile bir ejderhanın dövüş sahnesi tasvir edilmiştir. Behram-1 Gur, bir pençesini kahverengi bir ağaca destekleyen ve ağzından ateş püskürten ejderhayı öldürmektedir. Ejderhada kahverengi renk tercih edilirken ağzından püskürttüğü alev ve gökyüzündeki bulutlar altın ile renklendirilmiştir. Ejderha ile Behram-1 Gur arasında grili beyazlı yılanbaşlarından oluşan bir duman bulutu betimlenmiştir. Kompozisyonda detaylar koyu pastel tonda renklerin tercihinden geri planda kalmıştır. Mekân olgusuna az yer verilirken figürler ön planda resmedilmiştir. Minyatürün menşei XV. yüzyıl ortalarını muhtemelen İran'ın güneydeki Şiraz'ı ifade etmektedir.

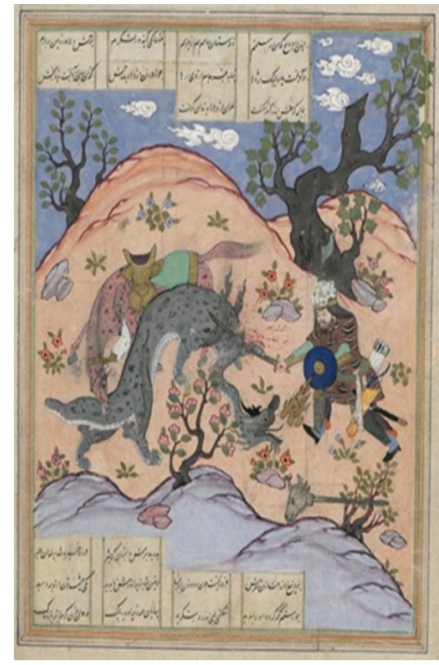

Resim 2. Rüstem ve atı bir ejderhayı öldürür (Berlin Devlet Kütüphanesi, VOHD 16,1,414)

Şehname, Berlin Devlet Kütüphanesi, VOHD 16,1,414 envanter kayıtlı, Diez A fol. 1, f.99v numara ile sınıflandırılmış yazma eserin Müellifi Ebu el- Kasım Mansûr ibn Hasan Firdevsi'dir (935-1020). Müstensihi Yusuf bin Hü̈seyin bin Yusuf Kâtib. Nüsha 1002 H./1593 M. tarihli ve dili Farsçadır. Eser 809 varaktan oluşmaktadır. Yazma eserin içerisinde 31 minyatür bulunmaktadır. Mevcut nüshası 1002 H.7/1593 M. olan 16. yüzyılın sonlarına tarihlendirilen eserin sayfa boyutu $32,5 \times 21 \mathrm{~cm}$, minyatür ölçüleri ise $15,5 \times 14,6 \mathrm{~cm}$ ölçülerindedir. Konusu şiir olan eser yaklaşık 60.000 ayetten oluşan Fars kahramanlık destanı anlatmaktadır. Nestalik hattı ile yazılmış bir eserdir.

Minyatürde Rüstem ile bir ejderhanın savaşması betimlenmiştir. Engebeli bir manzarada Rüstem, atı yardımıyla bir ejderhayı öldürmektedir. Rüstem kılıcını ejderhanın gövdesine saplarken atı; ejderhayı kuyruğundan yakalamış bir şekilde betimlenmiştir. Rüstem ejderhanın alevini engellemek için lacivert kalkanını siper alarak kendini savunur bir şekilde tasvir edilmiştir. Rüstem'in beline bağlı yay ve oklar savaşçının detaylarındandır. İki büyük dağ arasında ve arkasında ağaç tasvirlerine yer verilmiştir. Minyatürün ön tarafinda betimlenen küçük ağacın arasında boğa kafası formunda bir kılıç, dağlar, küçük kaya ve kır bitkilerinden oluşan bir doğa tasviri yapılmıştır. Hayvanlardan at ve ejderha figürü yer almıştır. Tasvirde incelik göze çarparken renkler soft olarak ele alınmıştır. Figürler orantılıdır. Kompozisyonda savaş sahnesi vurgusu iyi yansıtılmıştır.

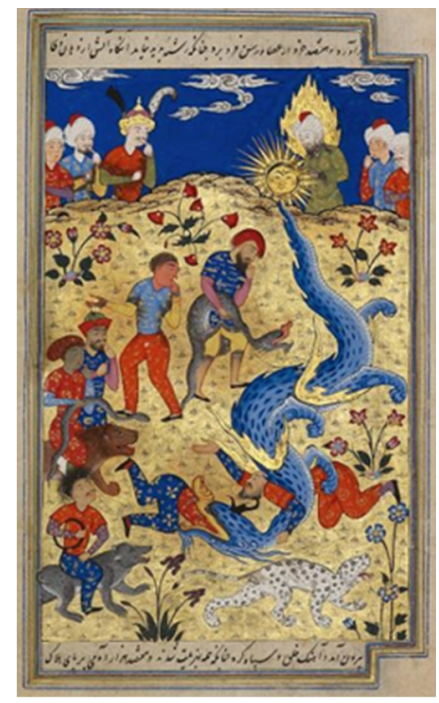

Resim 3. Hz. Musa Peygamberin asasının dönüşümü (Berlin Devlet Kütüphanesi, VOHD 16,1,385) 
Kısas-1 Enbiya, Berlin Devlet Kütüphanesi, VOHD 16,1,385 envanter kayıtlı, Diez A fol.3,f.106v numara ile sınıflandırılmıştır. Yazma eserin Müellifi İshak bin İbrahim bin Mansur bin halef en-Nişaburi'dir. Dili Farsça olan eser 984 H./1577 M. tarihlidir. İlk yaprağı boş olan eserin, 246 orijinal varağı bulunmaktadır. Yazma

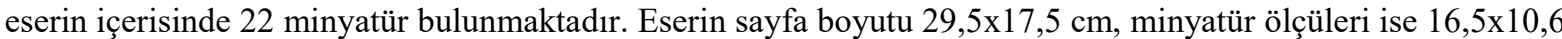
cm ölçülerindedir. Konusu biyografi, vaaz olan eserin içeriği Peygamber efendimiz Hz. Muhammed (S.A.V.) önceki peygamberler ve dört halifeyi anlatan konulardan oluşmaktadır. Eserin yazısında komutlar talik ile içerik ise nesih hattı ile yazılmıștır.

Minyatürde Hz. Musa Peygamberin asasının dönüşümü tasvir edilmektedir. Muhteviyatı dini konulu olan minyatürde Hz. Musa peygamber, Firavun, askerleri ve bir grup insan tasvir edilmiştir. Hz. Musa Peygamber asasını fırlatınca dev bir mavi-gri altın kanatları olan ateş püskürten ejderha olmuştur. Yılanları olan kötü büyücüler korkarak geri kaçar şekilde tasvir edilmiştir. Hz. Musa peygamberin dönüştürülmüş asasından insanlar korkarak sahnenin kenarına yönlenirler. Taçlı Firavun ve mahiyetindekiler, mucizeyi şaşkın bir şekilde izler şekilde betimlenmiştir. Hz. Musa peygamberin yanındakiler dönüşüme hayran kalmış bir durumda resmedilmiştir. Arka planda başında hale ile tasvir edilen Hz. Musa peygamber ve kişileştirilerek yapılmış bir güneş betimlemesi yer almaktadır. Güneş'in ve $\mathrm{Hz}$ Musa Peygamberin halesinin altın ile renklendirilmesi olayın görkemini ortaya koymak ister niteliktedir. Figürlerde mavi ve turuncu kıyafetler, doğada ise renkli bitkiler betimlenmiştir. Hayvan figürlerinden ejderha, yılan, leopar, kurt, ve domuz betimlenmiştir.

Minyatürün menşei Şiraz’1 ifade etmekle beraber tasvirler olağanüstü incelik ve renklerinin zenginliği ile karakterize edilmiştir. Figürler küçük ama iyi orantılıdır. Kompozisyon güçlü ve etkileyicidir. Renkleri parlak kontrast efektleri içermektedir. Eserin stili de minyatürlerin ayrıntılarında değişmekle beraber 16. yüzyılın son çeyreğinde büyük ölçüde Şiraz okulunun çerçevesi içerisinde kalıyor.

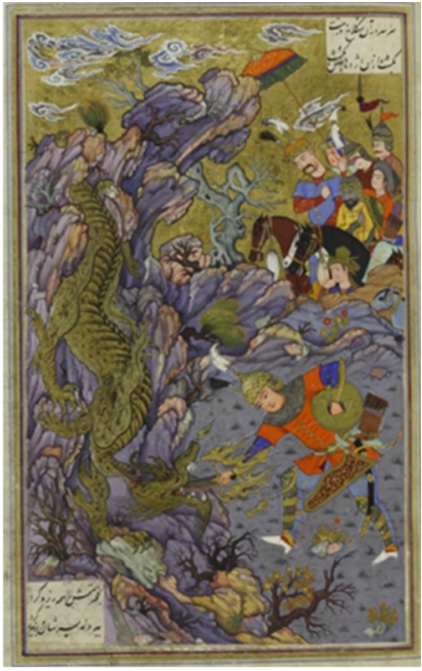

Resim 4. Garshasp bir ejderhayı öldürür (Berlin Devlet Kütüphanesi, VOHD 16,1,3)

Şehname, Berlin Devlet Kütüphanesi, VOHD 16,1,30 katalog, Ms. or.fol. 4251,f.56r numara ile sınıflandırılmıştır. Yazma eserin Müellifi Firdevsi, Abâ al-Kâsim Mansûr bin Ḥasan Firdevsî'dir. Dili Farsça olan eser 1014/27.06.-06.07.1605 tarihlidir. Eser, 764 varaktan oluşmaktadır. Yazma eserin içerisinde 67 tam sayfa minyatür bulunmaktadır. Mevcut nüshanın minyatürleri XVII. yüzyılın başına tarihlendirilmektedir. Eserin sayfa boyutu 36x24 cm, minyatür ölçüleri 22x14 cm ölçülerindedir. Eser Arapça talik hattı ile yazılmıştır.

Minyatürde Güştasp'ın ejderha ile savaşı tasvir edilmiştir. Kayalıkların üzerinden gelen kocaman yeşil bir ejderhanın nefes vermesiyle Güştasp'ın boğazına kılıcı saplaması tasvir edilmiştir. Arka planda yedi figürde ise eylemi izleyen biniciler ve miğferleri olan savaşçılar resmedilmiştir. Hayvan figürlerinden atlar ve ejderha tasvir edilmiştir. Lila gri kayaların üzerinde altın bulutlu gökyüzü betimlenirken figürlerin kıyafetlerde turuncu, yeşil, mavi gibi renkler tercih edilmiştir. Doğa tasviri ve ejderhada yeşil ve yeşilin tonları kullanılmıştır. Kayalıklarda lila ve mor tonları yoğun bir şekilde kullanılmıştır. Kompozisyonun mekân olgusunda savaş sahnesi vurgulanır nitelikte kayalıklarla dolu dağlık bir arazi tasviri yapılmıştır. Figürlerden Ejderha ve Garshasp (Savaşçı) ön plandadır. Kompozisyonda detay ve inceliğe önem verilmiştir. 


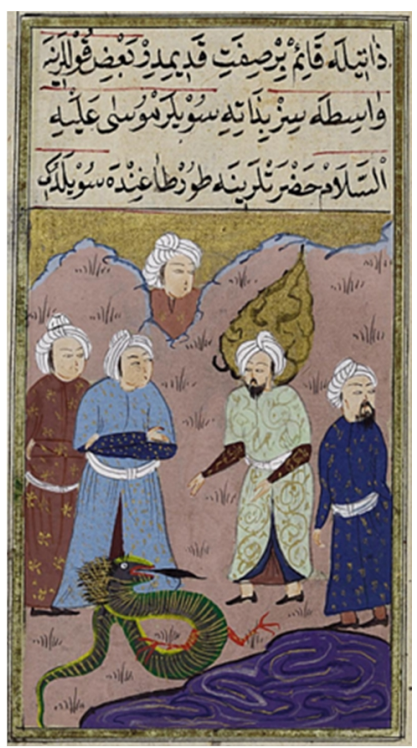

Resim 5. Hz. Musa Peygamberin asasının dönüşümü (Berlin Devlet Kütüphanesi, VOHD 13.3, 31)

Akaid-i Kelam, Berlin Devlet Kütüphanesi, VOHD 13.3, 31envanter kayitlı Ms. or. oct. 3797, f.19r, numara ile sınıflandırılmıştır. Yazma eserin Müstensihi Şeyh'Alî al-Șadr al-Konevi'dir. Dili Osmanlı Türkçesi olan eserin kopyalama tarihi 1173/1759'dir. Eserde, 227 varak bulunmaktadır. Yazma eserin içerisinde 8 minyatür bulunmaktadır. 18. yüzyılın sonlarına tarihlendirilen eserin sayfa boyutu 16x10 cm ölçülerindedir. Konusu İslam dininde gerekli esasları kapsayan Akaid kelam (Yavuz, 1989, s. 212-216) olup muhteviyatında Muhammed İbn-Pîr-'Alī el-Birgevi’ye ait Vasiyetname Şerhi yer almıştır. Eser nesih hattı ile yazılmıştır.

“Hz. Musa'nın asâsının bir yılana dönüşüp sihirbazların halka yılan şeklinde gösterdikleri ipleri ve sopalarını yutması üzerine sihirbazların secdeye kapanarak, "Hârûn'un ve Hz. Musa'nın rabbine iman ettik" dedikleri beyan edilir" ki (Taha Sûresi ayet 47-79), (Topaloğlu, 2010, s. 379-380) bu minyatür sahnesinde de Hz. Musa'nın asasının dönüşümü ile şaşkına dönen figürler yer almaktadır. Yılanın önünde bulunan mor zemin üzerindeki ipler Taha suresinde geçen ifadelerin tasviridir.

Minyatürde başında altın ile renklendirilmiş halesi olan Hz. Musa Peygamber ve üç figür tasvir edilmiştir. Yılan figürü ise Hz. Musa Peygamberin ve yanında kafalarında sarık bulunan üç adamın önünde dilini çıkarmış bir şekilde betimlenmiştir. Arka planda, tepelerin ardında hummalı genç bir adam bulunmaktadır. Eserde koyu mor, mavi, kahverengi ve açık yeşil elbise renkleri tercih edilirken doğada soft renkler kullanılmıştır. Ejderha yılanı ise yeşil üzerine sarı ve siyah renklerle detaylandırılmıştır. Kompozisyonun mekân tasviri sade bir şekilde ele alınmıştır. Figürlerde detaya çok yer verilmemiştir

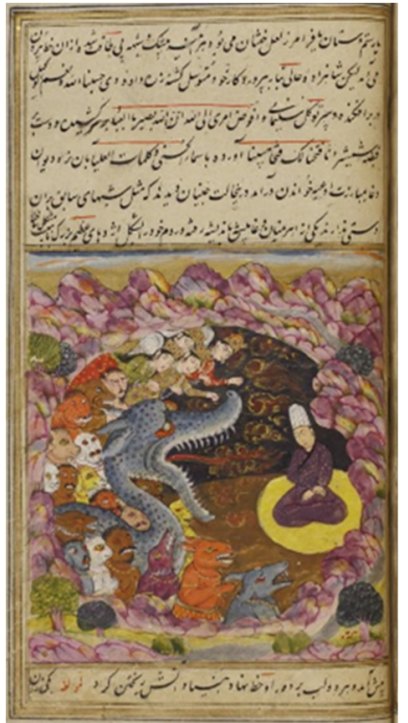

Resim 6. Efsanevi yaratıklar mağarada uyuyan Vâmık’1 kuşatır (Berlin Devlet Kütüphanesi, VOHD 16,1, 69) 
Vâmık u Azrâ, Berlin Devlet Kütüphanesi, VOHD 16,1, 69 Kramer 72 katalog, PPN: 735128383 numara ile sınıflandırılmıştır. Yazma eserin Müellifi Mirza İbrahim Kirmânî'dir. Dili Farsça olan eserin tarihi hakkında net bir bilgi yoktur. Eserin orijinal nüshası için farklı düşüncelere rastlanmıştır (Tokmak, 2012, s. 504-505). Eser 245 varaktan oluşmaktadır. Yazma eserin içerisinde 86 sayfa minyatür bulunmaktadır. Mevcut nüsha 1800'lü yılların üslubunu yansıtmaktadır. Eserin sayfa boyutu 28,5x17 cm, minyatür ölçüleri $13 \times 12 \mathrm{~cm}$ ölçülerindedir. Eser talik hattı ile yazılmıştır. Metin kafiyeli nesir yazılar ve ayetlerden oluşan karışık bilgileri ihtiva etmektedir.

Lake bir cilde sahip olan eserin üst kapağında çiçek buketleri yer alırken alt kapağında bir minyatür betimlemesi yer almıştır. Efsanevi yaratıkların mağarada uyuyan Vâmık'1 kuşatması minyatüründe ejderha figürü uyuyan Vâmık'a doğru ateş püskürtmesi ile tasvir edilmiştir. Gri-beyaz üzerine siyah benekler ile renklendirilen ejderha çeşitli acaibül mahlûkatların arasında resmedilmiştir. Kompozisyonda mekân tasviri karmaşık bir algı yaratsa da figürlerdeki renk, tahrir ve detay uygulamaları net bir şekilde betimlenmiştir. Minyatürün menşei Kuzey Hindistan, kısmen Babür stilinde olduğu düşünülmektedir.

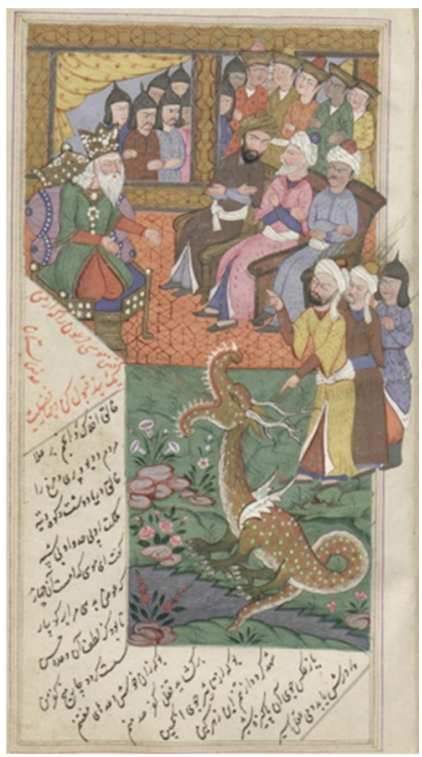

Resim 7. Hz. Musa Peygamberin Asasının Dönüşümü (Berlin Devlet Kütüphanesi, VOHD 16.1)

Mesnevi, Berlin Devlet Kütüphanesi, VOHD 16.1, katalog, 3748, f.34r numara ile sınıflandırılmıştır. Yazma eserin Müellifi Mevlana Celaleddin el Rumi'dir (672/1273). Dili Farsça olan eserin tarihi hakkında net bir bilgi bulunmamaktadır. Eser 188 varaktan oluşmaktadır. Yazma eserin içerisinde 9 sayfa minyatür bulunmaktadır. Mevcut nüshanın minyatürleri modern resimlerinden ötürü XIX./XX. yüzyıl üslubunu çağrıştırmaktadır. Eserin sayfa boyutu $21 \times 12,5 \mathrm{~cm}$, minyatür ölçüleri 15,5x5 cm ölçülerindedir. Eser nestalik hattı ile yazılmıştır. Altı ciltten oluşan eserin metni tasavvufi şiirleri ihtiva etmektedir

Minyatürde Hz. Musa Peygamberin asasının dönüşümü gösterisi yapılmıştır. Tahtta oturan başında taç bulunan, beyaz sakallı yaşlı bir adam, karşısında koltukta oturan üç ziyaretçiye bir şeyler anlatmaktadır. Arka planda, sekiz miğferli savaşçı ve beş adam kollarını bağlamış bir şekilde, iki büyük pencereden anlatılanları dinler vaziyette resmedilmiştir. Ön planda başında sarık bulunan iki adam ve bir savaşçı, ağzını açmış tıslayan bir ejderha betimlenmiştir. Mekân olgusunda ejderha dönüşüm sahnesi bahçe içerisinde resmedilmiştir. Ejderha figürü bu minyatürde kanatlı ve boynuzlu betimlenmiştir. Figürlerin ayrıştırıcı renkleri, elbiselerdeki kıvrımalar, incelikli bezeme, geometriksel ve zencerek detayları sahneyi canlı tutmuştur. Minyatürde sarı, mavi, kahverengi, turuncu, yeşil, pembe gibi renkler kullanılarak hareketli bir kompozisyon ortaya konulmaya çalışılmıştır.

Berlin Devlet Kütüphanesinde ejderha betimlemeli yaklaşık 84 minyatüre rastlanmıştır. Kütüphanedeki ejderha tasvirli minyatürleri genel olarak ele aldığımızda en sık rastladığımız sahne Ejderhaların kahramanlarla (İskender, Güstaşp, Rüstem, Behram Gur, İsfendiyar, Garsasp) savaşı olmuştur. Öte yandan sık karşılaştığımız bir tasvir biçimi de Acaibü’l Mahlûkat nüshalarında tek başına resmedilmiş ejderha figürleridir. Ejderhaların Simurg ve benzeri hayvanlar ile mücadele sahneleri, Musa peygamberin asasının dönüşümü gibi konuları sıkça ele alınmıştır. Kütüphanedeki aşk mesnevilerinden Leyla ve Mecnun, Vâmık u Azra gibi eserlerde de ejderha figürlerine rastlanmıştır.

Berlin Devlet Kütüphanesindeki XV ile XX. yüzyıl arasından seçilen, ejderha konulu minyatür eserleri incelenmiştir. Araştırmanın giriş kısmında açıklanan semboller göz önüne alınarak ele alınan minyatürler 
değerlendirildiğinde savaş sahnelerindeki (Resim 1 Resim 2, Resim 4) ejderha figürü; güç, erdem unsuru metaforu ile özdeşleşmektedir. Ejderha figürünün sıkça yer aldığı diğer bir tasvir konusu olan Musa'nın asasının dönüşümündeki metafor ise (Resim 3) irade ve hâkimiyet ile bağlantılıdır. Așk mesnevilerinden olan Vâmık u Azra (Resim 6) eserindeki tasvirde; tehlikeye karşı güç ögesi kullanılmaktadır. Mevlana'nın Mesnevisi tasavvuf bağlamında kullanıldığından nefsi ifade etmektedir (Resim 7). Dini konu ve kuramları içeren Akaid-i Kelam (Resim 5) eserinde yılan tasviri ilahi güç unsurunu temsil etmektedir.

Minyatürlerdeki ejderha figürlerinin sahne ve mekân kurguları da değerlendiğinde metinde anlatılan efsane ile ejderhaların tasvir edildiği mekânlar arasında doğrudan bir ilişkilendirme vardır. Ejderhaların tasvir edildiğgi mekân olgusu özelliklerine bakıldığında çoğunlukla dağlı bir alan ve çok büyük boyutta resmedilen ejderha figürleri görülmüştür. Öte yandan mağarada tasvir edilen bir ejderha figürü ve saray önünde doğada tasvir edilmiş bir ejderha betimlemesine yer verilmiştir. Yine bu figürlerin güç unsurlarını ifade edebilecekleri bir mekân algısı yaratılmıştır. Minyatürlerdeki mekân anlayışı üzerinde Konak (2014)'e göre “mekân, resme konu edilen şeylerin kendi oluşlarını dışa vurmalarına olanak sağlayan bir içyapı olduğu kadar, şeyleri bulunduğu düzlemde bütüne eklenmeleri açısından tanımlayan dış yapı olma özelliği de gösterir. Zira minyatür sanatında mekân, sanatçı öznenin bakış açısına dayalı derin görüntüden çok nesnel ortamın kendi oluşuna yoğunlaşan, onun oluşunu yüzeyin olanakları doğrultusunda ve biçimin elverdiği oranda tasvir etmeye yönelik bir şema özelliği gösterir" (Konak, 2014, s. 34-54) R. Konak’ın ifadeleri minyatürdeki mekân betimlemelerini geniş ölçüde kavramaya yönelik bir bilgidir. Konu nesnel ortam bakımından yararlandığ gerçeklik durum ile natüralist; tasarlanmış gerçeklik durum açısından da soyut bir resim (Konak, 2007, s. 98) olan minyatürlerin soyutlaştırılmış ögeleri, doğa, figür, eşya tasvirleri mekân kurgusunda ifade edilmek istenen sahneye göre biçim almaktadir.

Minyatürlerin renk değerlendirmesinde ise doğal nesne ya da kişilerin, perspektif ve gölgeye dayanarak, doğrudan bir portresi çıkartılmaya çalışılmaz. Bu betimlemelerde doğa tasvirleri imgeselleştirilmiş ve idealize edilmiş bir şekilde karşımıza çıkmaktadır. Ağaç, taş ya da ırmak gibi doğal nesneler ancak doğal renklere hiç benzemeyen renkler ile gerçek dişı şekilde bir araya getirilebilir. Bilhassa renklerin harmanlanması sonucu harikulade parlak, dengelenen ve bütünlük sergileyen (Saraç, 2011, s. 175) uyum içerindeki tasvirler görülebilir. Minyatür sahnelerindeki ejderha figürlerinin renklerinde kahverengi-siyah, gri-beyaz, mavi-beyaz, yeşil-siyah, yeşil-sarı, yeşil-beyaz gibi renkler kullanıldığı tespit edilmiştir. Parlak, canlı, bütüncü ve tamamlayıcı olarak kullanılan renkler sanatçının tasavvuruna göre şekillenmiştir.

Araştırma ve incelemede minyatürlerdeki ejderha figürlerinin metaforu incelenirken minyatürlerin konusu, özellikleri, renk ve mekân tasvirleri yapılmıştır. Minyatür değerlendirmeleri, bilgileri verilmiştir.

\section{Sonuç}

Ejderha figürü örnekleri minyatür sanatında yaygın olarak tasvir edildiği görülmüştür. İncelenen minyatürlerdeki ejderha resimlerinin ikonografik çözümlemesi minyatürün muhtevasındaki hayvan figürünün özellikleri ya da simgelere atfedilen mananın doğrultusunda metafor ile özdeşleştiği düşünülmektedir. Ejderhalar çeşitli özellikleri ile farklı şekillerde resmedilmiştir. Çoğu zaman iri cüsseli, iri gözlü olarak betimlense de bazı tasvirlerde ise çok büyük ejderha yılanı olarak tanımlandığı bilinmektedir. Birçok tasvirde ağzından alevler çıkararak resmedilen ejderhalar, yılan figürü olarak tasvir edildiğinde uzun, kocaman bir gövdesi ve dili dışarda betimlenmiştir. Bazı ejderhalar kanatlı tasvir edilirken bazıları boynuzlu betimlenmiştir. Ele aldığımız minyatürlerde ejderha figürleri tek başlı ele alınmıştır. Ancak ejderha tasvirlerinde iki, yedi ya da birden çok başı olan olağanüstü varlıklar olarak da karşımıza çıkmaktadır. Ejderha tasvirlerinin mitik unsurlar ile simge biçimini aldığı görülmüştür.

Araştırmanın sonucunda Ejderha figürlü minyatürlerin metaforik ikonografisi incelenmiştir. Türk sanatında Ejderha öldürme sahneleri, özelikle İran padişahlarını konu alan minyatürlerde sıkça karşımıza çıkan Ejderha figürü Behram Gur, Güştasp, Rüstem gibi kahramanların savaş sahnelerinde savaşçının kendisini evrene gücünü kanıtlama ve hükümran olma isteğini düşündürmekle beraber, güç unsuru ile özdeşleşmiş bir metafor olarak ortaya çıkmaktadır. Bazı minyatür tasvirlerinde ise ejderha yılanı olarak karşımıza çıkmaktadır. Yılan olarak tasvir edildiğinde su, gök ve yer unsurlarına işaret etmektedir. Hayvanların metaforları üzerine geniş bilgiler içeren Mevlana'nın Mesnevi'sinde ise ejderha yılanı nefis olarak sembolize edilmektedir.

İyi ve kötü kavramlar ile ejderha figürüne yüklenen karakterler, insan düşüncesindeki farklı değerlendirmeler ile yılan ya da ejderha olarak resmedilmiştir. Farklı anlamlar kazanarak minyatürlerde yer almıştır. Metaforlar bir yandan üstü kapalı mesajlar içermektedir. Bir figürün neyi ifade etiğini kavramaya çalışmanın yanı sıra dayandırılan anlamlarının gerçek ve gerçek üstü manalar taşındığı anlaşılmıştır. Güç, gök, su, yer temsili, bolluk, nefis, yeniden doğuşun sembolü, şimşek ve bereket gibi simgelerin ifadesi olan ejderha figürü hayatın dengesini sağlayan temsili anlam ve çeşitli sembollerle minyatürlerde betimlendiği sonucuna varılmıştır. 
Toplumların gelişim süreci içerisinde ortaya çıkan, değer ve olgular ile kültürden kültüre değişim gösteren metaforlar kültür, coğrafya, toplum, tarih gibi etkenler ile şekil almaktadır.

\section{Kaynakça}

And, M. (2004) Osmanlı tasvir sanatları:1 minyatür. İstanbul: Türkiye İş Bankası Yayınları.

And, M. (2007). Minyatürlerle Osmanl-İslam mitologyası, (6. baskı). İstanbul: Yapı Kredi Yayınları.

Çoruhlu, Y. (1993). Íslamiyet'ten önceki Türk sanatında hayvan mücadele sahneleri. İkonografik araştırmalar: Güner İnal'a Armağan (s. 117-141) içinde. Ankara: Bizim Büro Basımevi.

Çoruhlu, Y. (2014). Türk sanatında hayvan sembolizmi. Konya: Kömen Yayınları.

Eke, N. U. (2016). Şâhidî’nin şiirlerinde tasavvufi metaforlar. Osmanlı Mirası Araştırmaları Dergisi, 5(3), 1224.

Ersoy, N. (2007). Semboller ve yorumları. İstanbul: Dönünce Yayınevi.

Esin, E. (2003). Orta Asya'dan Osmanlıya Türk sanatında ikonografik motifler. İstanbul. Kabalcı Yayınevi.

Lakoff, G., \& Johnson, M. (1980). Metaforlar hayat, anlam ve dil (G. Y. Demir, Çev.). İstanbul: Deniz Ofset Matbaacilik.

Gökçimen, A. (2010). Türkmen masallarında mitolojik hayvanlar ve fonksiyonları. Türkbilig Türkoloji Araştırmaları Dergisi, 20, 165-178.

Keklik, N. (1990). Felsefede metafor. İstanbul: İstanbul Üniversitesi Edebiyat Fakültesi Yayını.

Konak, R. (2014). Minyatür sanatında boşluk ve mekân anlayışı, Akdeniz Sanat Dergisi, 7(14), 34-54.

Konak, R. (2007). Minyatür sanatında derinlik anlayışı. Atatürk Üniversitesi Güzel Sanatlar Fakültesi Sanat Dergisi, 12, 97-102.

Konukçu, E. (1992). “Behram-1 Gûr”, İslam ansiklopedisi, (Cilt.5, s. 453). İstanbul: Türkiye Diyanet Vakfi Yayınlar1.

Mahir, B. (1993). Osmanlı saz üslubu resimlerinde ejder ikonografisi. İkonografik Araştırmalar: Güner İnal'a Armağan (s.271-294) içinde. Ankara: Bizim Büro Basımevi.

Nur, İ. H. (2013). Mesnevi’de hayvan karakterleri (Metaforları), Avkae Dergisi, 3, 18-30.

Ocak, A. Y. (1983). Bektaşî menakıbnamelerinde İslâm öncesi inanç motifleri. Ankara: İletişim Yayıncılık.

Onay, A. T. (1992). Eski Türk edebiyatında mazmunlar ve izahı. Ankara: Türkiye Diyanet Vakfı Yayınları.

Öğel, B. (2002). Türk mitolojisi: (Kaynakları ve açıklamaları ile destanlar). (Cilt. 1). Ankara: Türk Tarih Kurumu Yayınları.

Özkeçeci, İ., \& Özkeçeci, Ş. (2007). Türk sanatında tezhip. İstanbul: Seçil Ofset.

Roux, J. P. (2005). Orta Asya'da kutsal bitkiler ve hayvanlar (L. Arslan, Çev.). İstanbul: Kabalcı Yayınevi.

Saraç, S. Y. (2011). İslam halklarının sanatsal anlatım yöntemleri “Minyatür”, Journal of Islamic Research, 4(1), 171-194.

Şahan, K. (2014). Türk şiirinde metafor (1923-1960) (Doktora Tezi). Trakya Üniversitesi Sosyal Bilimler Enstitüsü, Trakya. YÖK tez veri tabanından erişildi (Tez No. 370411).

Tez, Z. (2008). Mitolojinin kültürel tarihi doğu ve İslam mitolojisi mitolojik söylenceler. İstanbul: Doruk Yayınc1lik.

Toscanne, P. (1911). Etudes sur le serpent, figure et symbole dans l'antiquitê êlamite. XII. Dêlêgation en Perse, Memoires toplantısında susnulan bildiri, Paris, France.

Topaloğlu, B. (2010). “Taha Süresi”, İslam ansiklopedisi, (Cilt. 39, s. 379-380). İstanbul: Türkiye Diyanet Vakfi Yayını.

Tokmak, A. N. (2012). "Vâmık ve Azra", İslam ansiklopedisi, (Cilt. 42, s. 504-505). İstanbul: Türkiye Diyanet Vakfi Yayını.

Yıldırım, N. (2012). Iran mitolojisi. İstanbul: Pinhan Yayıncılık.

Yurdaydın, H. G. (1954). İslam resminin menşeleri ve başlangıçları. Ankara: Türk Tarih Kurumu. 
Yavuz, Y. Ş. (1989). “Akaid Kelam”, İslam Ansiklopedisi (Cilt. 2, s. 212-216). İstanbul: Türkiye Diyanet Vakfı Yayını.

\section{Görsel Kaynakçası}

Resim 1. Berlin Devlet Kütüphanesi Yazmaları, (2018), Behram-1 Gur ile bir ejderhanın dövüşs sahnesi/Behram-1 Gur and a dragon fighting scene [Yazma Eser-Minyatür]. Erişim adresi: https://digital.staatsbibliothekberlin.de/werkansicht/?PPN=PPN729902676\&PHYSID=PHYS_0428

Resim 2. Berlin Devlet Kütüphanesi Yazmaları, (2018), Rüstem ve atı bir ejderhayı öldürür/Rustem and his horse kill a dragon [Yazma Eser-Minyatür]. Erişim adresi: https://digital.staatsbibliothekberlin.de/werkansicht/?PPN=PPN671782010\&PHYSID=PHYS_0204

Resim 3. Berlin Devlet Kütüphanesi Yazmaları, (2018), Musa peygamberin asasının dönüşümü/Transformation of the baton of the Prophet Moses [Yazma Eser-Minyatür]. Erişim adresi: https://digital.staatsbibliothek berlin.de/werkansicht/?PPN=PPN615574084\&PHYSID=PHYS_0218

Resim 4. (Berlin Devlet Kütüphanesi, VOHD 16,1,3), (2018), Garshasp bir ejderhayı öldürür/Garshasp kills a dragon [Yazma Eser-Minyatür]. Erişim adresi: https://digital.staatsbibliothekberlin.de/werkansicht/?PPN=PPN731525744\&PHYSID=PHYS_0117

Resim 5. (Berlin Devlet Kütüphanesi, VOHD 13.3, 31), (2018), Musa peygamberin asasının dönüşümü/Transformation of the baton of the Prophet Moses [Yazma Eser-Minyatür]. Erişim adresi: https://digital.staatsbibliothek-berlin.de/werkansicht/?PPN=PPN742529878\&PHYSID=PHYS_0041

Resim 6. (Berlin Devlet Kütüphanesi, VOHD 16,1, 69), (2018), Efsanevi yaratıklar mağarada uyuyan Vâmık’1 kuşatır/Legendary creatures surround Vâmık sleeping in the cave [Yazma Eser-Minyatür]. Erişim adresi: https://digital.staatsbibliothek-berlin.de/werkansicht/?PPN=PPN735128383\&PHYSID=PHYS_0435

Resim 7. (Berlin Devlet Kütüphanesi, VOHD 16.1), (2018), Musa peygamberin asasının dönüşümü/Transformation of the baton of the Prophet Moses [Yazma Eser-Minyatür]. Erişim adresi: https://digital.staatsbibliothek-berlin.de/werkansicht/?PPN=PPN638281598\&PHYSID=PHYS_0071 